DOI: https://doi.org/10.34069/AI/2021.43.07.25

How to Cite:

Simonova, S.A., Shvetsova, T.V., Shtanko, M.A., Bronnikov, D.G., \& Mikhailov, A.A. (2021). Leo Tolstoy's moralizing in context of ethical and aesthetic synthesis. Amazonia Investiga, 10(43), 257-263. https://doi.org/10.34069/AI/2021.43.07.25

\title{
Leo Tolstoy's moralizing in context of ethical and aesthetic synthesis
}

\section{Морализаторство Льва Толстого в контексте этико-эстетического синтеза}

\author{
Received: May 2, $2021 \quad$ Accepted: july 26, 2021
}

\author{
Written by: \\ Svetlana A. Simonova ${ }^{90}$ \\ https://orcid.org/0000-0003-4506-1248 \\ SPIN: 5141-2502 \\ Tatiana V. Shvetsova91 \\ https://orcid.org/0000-0001-9637-6958 \\ SPIN: 8251-1780 \\ Marina A. Shtanko ${ }^{22}$ \\ https://orcid.org/0000-0003-2665-2552 \\ SPIN: 4867-9385 \\ Denis G. Bronnikov ${ }^{93}$ \\ https://orcid.org/0000-0002-0382-4414 \\ SPIN: $6467-0780$ \\ Alexei A. Mikhailov 9 \\ https://orcid.org/0000-0002-2222-5708 \\ SPIN: 6571-2725
}

\begin{abstract}
The article examines the moralizing of Leo Tolstoy on the example of his theoretical ideas. The authors, examining their genesis, come to the conclusion that the writer formed his ideas under the influence of French enlighteners and sentimentalists, on the one hand, and absorbed the ethical dominant of Russian culture, on the other hand. The article analyzes the idea of absolutizing good, which runs through Tolstoy's entire aesthetic theory as a leitmotif. As a result of the study of the aesthetic views of the writer, it is concluded that Tolstoy understood the role of art solely as a translation of feelings and a means of communication. The writer deprives art of its aura of mystery and does not recognize the latter as a source of aesthetic pleasure and spiritual enrichment. The article analyzes the worldview of the writer, reveals the influence on him of the experience acquired by Tolstoy in childhood and adolescence. Tolstoy's works of art and theoretical views are another example of the fact that the artist's worldview does not always coincide with his work.
\end{abstract}

\begin{abstract}
Аннотация
В статье исследуется морализаторство Льва Толстого на примере его теоретических идей. Авторы, исследуя их генезис, приходят к выводу, что писатель сформировал свои идеи под влиянием французских просветителей и сентименталистов, с одной стороны, и впитал в себя этическую доминанту отечественной культуры, с другой стороны. В статье анализируется идея абсолютизации добра, которая лейтмотивом проходит сквозь всю эстетическую теорию Толстого. В результате исследования эстетических взглядов писателя, делается вывод о понимании Толстым роли искусства исключительно как трансляции чувств и средства общения. Писатель лишает искусство ореола таинственности и не признает последнее в качестве источника эстетического наслаждения и духовного обогащения. В статье анализируется мировоззрение писателя, выявляется влияние на него опыта, приобретенного Толстым в детстве и юности. Художественные произведения
\end{abstract}

\footnotetext{
${ }^{90}$ Doctor of Philosophical Science, Professor, Moscow State University of Psychology \& Education (MSUPE). Moscow, Russia.

${ }^{91}$ Candidate of Philology, docent, Federal University named after M.V. Lomonosov (NarFU). Arkchangelsk, Russia.

92 Taganrog Institute of Management and Economics, Taganrog, Russia.

${ }^{93}$ The Kosygin State University of Russia. Moscow, Russia.

${ }^{94}$ Doctor of Pedagogical Sciences, Professor, Director of Shuya Branch of Ivanovo State University, Ivanovo, Russia.
} 
Keywords: moralism, art, didactics, ethical and aesthetic synthesis, Christian values.

\section{Introduction}

In modern times, rehabilitation and new substantiations of the essence of spiritual values are in demand, the basis of which is the synthesis of ontology, ethics and aesthetics. Recently, a tendency has developed to consider worldview simplifications as the norm, to justify the decay of values, the aestheticization of being, and in general, to present the above as a natural evolution of culture, a natural socio-cultural process. Researcher Paramonov spoke about modern culture in the following way: today, the value of a person is no longer what is due, for modernity the given is paramount and present (Paramonov, 1999: 6). That is, any striving for the ideal is secondary in comparison with what is useful and pragmatic here and now.

The European tradition, in the destruction of the ancient synthesis of truth, goodness and beauty, alternately carried out the absolutization of the epistemological, ethical or aesthetic aspects of spiritual unity, which has led today to quite negative consequences. V.V. Bibikhin: "Modern man escapes into darkness from his own judgment. What to ask, when there is no one to answer. The person of the current day sees himself as a lonely, albeit prodigal, but a son who can no longer return to his father" (Bibikhin, 1998: 34).

In Russian culture, it is ethics that traditionally passes through the whole philosophy and works of art as a leitmotif. In this regard, P. Ye. Astafiev notes: "Our people are least of all a legal or political people, to a very weak degree - socioeconomic and in the highest degree - moral and moral-religious" (Astafiev, 1996: 95).

\section{Materials and methods}

In this article, we aim to identify the origins and specific features of Leo Tolstoy's moralizing based on an analysis of his aesthetic theory. To achieve this goal, we used methods such as axiological, comparative, dialectical, psychological analysis. The axiological method is necessary in the context of the study of the value attitudes of the Russian writer, which can теоретические взгляды Толстого являют очередной пример того, что мировоззрение художника не всегда совпадает с его творчеством.

Ключевые слова: морализм, искусство, дидактика, этико-эстетический синтез, христианские ценности.

be traced in his aesthetic theory. We used the method of comparative analysis in order to compare Tolstoy's moralism with the moral ideas of French enlighteners, Christian philosophers and contemporary Russian researchers. The psychological method was applied by us in the process of studying the life experience of a young writer, which had a certain influence on the formation of his value priorities. The dialectical method contributed to the study of Leo Tolstoy's philosophical views in the context of evolution and the interaction of his theoretical ideas and artistic creativity.

Based on the above, we have built the appropriate logic of the study. First, we investigated the genesis of the writer's Christian moralism, which in a certain sense were close to the ideas of the ancient Stoics and Western European moralists of the Enlightenment. In them one should look for the sources of Tolstoy's rationalism, withdrawal into social philosophy and his denial of mystical Christian revelation. Further, a simplified interpretation of art by the Russian writer was considered, where Tolstoy actually denies the role of aesthetic pleasure provided by art and the spiritual component of the latter. Finally, we revealed the discrepancy between his theoretical views of Tolstoy and his artistic work, filled with a synthesis of ethics and aesthetics.

\section{Results and discussion}

The emergence of such a phenomenon as "Russian moralizing" was facilitated, in our opinion, by a paradoxical interaction in the national consciousness of moral and legal or legal, leading to their almost tragic collision. In this regard, let us give as an example the reasoning of the scientist-ethicist V.P. Fetisov, concerning increased attention to moral values: "many moral assessments and norms may be monstrously backward compared to cultural and progressive countries, but our inclination to moral searches will still be stronger" (Fetisov, 1995: 4). 


\section{AMAZONIA}

One of the most striking and indicative phenomena in this context was the ethical and philosophical ideas of L.N. Tolstoy, a convinced moralizer who asserts in his theoretical judgments the ethical dominant of Russian culture. In his critical statements, the writer defended morality as the main component of human spirituality, thus belittling everything that is associated with aesthetics, relegating beauty to a secondary, auxiliary, consciously and purposefully destroying and denying the equal interaction of good and beauty. We emphasize, however, that in his works of art Tolstoy demonstrated the opposite.

Interest in the theoretical ideas of Leo Tolstoy is great enough, his contemporaries have already investigated their philosophical component. G. Florovsky believed that the genesis of the moralizing of the Russian writer should be seen in the specifics of Tolstoy's personality, his education and preferences, the cultural soil on which the writer grew up, which he perceived and creatively reworked. Florovsky characterized Tolstoy's philosophical outlook as "moral positivism", "moralistic robinsonade" and "moralistic casuistry".

Being a deeply religious thinker, Florovsky accuses Tolstoy of religious mediocrity. "He undoubtedly had the temperament of a preacher or a moralist, but he had no religious experience at all. Tolstoy was not at all religious, he was religiously mediocre" (Frolovsky, 1983: 404). It is with this fact that the philosopher explains Tolstoy's inclination to moral positivism, which has its origins in the philosophy of ancient Stoicism.

It is significant that some researchers superficially correlate the teachings of the Stoics with Christian ideas in an ethical context. However, while recognizing certain similarities, let us emphasize their fundamental divergence. Christian teaching is mystical, filled with revelations; the ideas of the Stoics are based on ethical rationalism, the virtue of the ancient philosophers of this direction is based on their strictly rationalized substantiation of the postulated moral convictions.

Tolstoy denies Christian mysticism, appealing to common sense and reason. Orthodox mystical Christian dogmas, such as the Trinity, the Incarnation, the Immaculate Conception of the Virgin Mary, the resurrection of Christ, Tolstoy cannot recognize, therefore, he either completely denies or transforms in accordance with his views, relying largely on the ideas of the enlighteners who build the architectonics of the picture of the world not multidimensionally and antinomically, but within the framework of social philosophy. G.G. Shpet emphasizes in this connection that the nature of moralizing consists in the absence of the tragic, because the latter is mystical in nature. "The tragic is both in the epic and in the lyrics. It is absent only in the novel, because it is moralizing about the tragic" (Shpet, 2007: 66)

The ethical and aesthetic views of Leo Tolstoy were exhaustively set forth in his work "What is art?", Therefore, let us analyze this work in more detail. A fragment of this treatise provides a key to understanding Tolstoy's ideological position, contains all his nihilistic, moralistic and aesthetic values: "The other day I was walking home from a walk in a depressed state of mind. Approaching the house, I heard the loud singing of a large round dance of women ... In this singing, with shouts and beating in a braid, such a definite feeling of joy, cheerfulness, energy was expressed that I myself did not notice how I became infected with this feeling and went to the house more cheerfully and approached it very cheerful and cheerful. In the same excited state, I found all the household members who listened to this singing. On the same evening, a wonderful musician who came to visit us, famous for his performance of classical, especially Beethoven's, things, played us the opus 101 Beethoven's sonata ...

At the end of the performance, it was obvious that everyone was getting bored, as expected, zealously praised Beethoven's thoughtful work ... Meanwhile, the song of the women was a real art that conveyed a definite and strong feeling. But Beethoven's 101st sonata was just an unsuccessful attempt at art, containing no definite feeling and therefore infecting nothing" (Tolstoy, 1985: 235-236).

Thus, Leo Tolstoy claims that, on the one hand, he observes "real art" (singing of women), on the other hand, it is just "an unsuccessful attempt at art" (Beethoven's sonata). The moralistic categorism of the Russian writer prevented him from fully realizing his critical work, from getting to the very origins of the negative state of art, science and culture of that time. Leo Tolstoy seems to stop halfway; where a deep, ontological insight into the essence of things should have been realized, the writer is limited only to discontent, petty criticism and utopian projects of a very dubious nature. The moralizing inherent in the writer becomes an obstacle to more promising and detailed research, makes it 
impossible to explore the phenomenon of art in all the multifaceted nature of its metaphysical possibilities.

In connection with the above, it seems to us quite natural the shocking nihilistic impulse of the Russian writer, in which he no longer denies not only Beethoven's work, but also other works of world culture. For example, Leo Tolstoy calls Aeschylus, Aristophanes, Sophocles, Euripides, Dante, Shakespeare, Goethe, Raphael, Michelangelo, Bach, Liszt and other representatives of the "golden fund" of human culture as "imitators".

This nihilism has a genesis that denies the classical trinity of truth, goodness and beauty at the cultural and philosophical level. It is no coincidence that Leo Tolstoy devotes the most important, philosophical part of his treatise "What is Art"? To the destruction of this triad.

Tolstoy doesn't accept the synthesis of this, in his opinion, "imaginary trinity". $\mathrm{He}$ argues that: "Scientists write long vague treatises about beauty as one of the members of the aesthetic trinity: beauty, truth and goodness ... In essence, these words not only have no definite meaning, but prevent the existing art from being given what - a certain meaning, and are needed only to justify the false meaning that we attribute to art, which conveys all kinds of feelings, as soon as these feelings give us pleasure" (Tolstoy, 1985: 179). In fact, this statement contains the main idea of Tolstoy's nihilistic pathos, which he tries to logically substantiate with the help of his hierarchy of spiritual values. At the highest level, the writer disposes of goodness.

"Goodness, beauty and truth are placed on the same level, and these concepts are recognized as basic and metaphysical. Meanwhile, in reality there is nothing of the kind. Good is the eternal, highest goal of our life. No matter how one understands good, our life is nothing but a striving for good, that is, for God" (Tolstoy, 1985: 180). On this occasion, it is appropriate to quote the words of the Russian philosopher Frank, who in his "Ethics of Nihilism", discussing the psychology of moralism, emphasizes that moralists, in particular, many Russian intellectuals, exaggerate the role of morality, placing it at the basis of the entire worldview. Frank concludes: "The Russian intellectual does not know any absolute values, no criteria, no orientation in life, except for the moral differentiation of people, actions, good and bad, good and bad" (Frank, 1990: 82).
Tolstoy in this context generally interprets beauty as something opposite to good: "The concept of beauty not only does not coincide with good, but rather opposite to it, since good for the most part coincides with the victory over addictions, beauty is the basis of all our passions" (Tolstoy, 1985: 180). That is, of all the multifaceted hypostases of beauty, the writer captures and recognizes only one - the ability to deliver pleasure, which he considers the main obstacle on the path to moral improvement. Therefore, in his opinion, the concept of beauty must be "removed" from both theory and practice.

Based on the foregoing, Tolstoy approaches art primarily from the point of view of morality and ideology, he simplifies its purpose, practically reducing it to a means of communication between people: "In order to accurately define art, one must first of all stop looking at it as a means of pleasure, but to consider art as one of the conditions of human life" (Tolstoy, 1985: 167).

But, ultimately, one of the most important functions of human culture is the communicative function, all forms of culture contribute to the communication of people. What, then, is the specificity of the phenomenon of art; why does it affect a person so powerfully, and does it not have the right to be immoral?

Tolstoy recognizes another property of art, which is the transmission of feelings. Art, following the logic of the writer, "communicates" with the help of feelings. And the writer gives him the following definition: "art is human activity, through which some people convey their feelings to others, and not a service to beauty or the manifestation of an idea ..." (Tolstoy, 1985: 168169). It follows that the main task of art is to "infect" the feelings of others. Thus, Leo Tolstoy declares infectiousness as the main criterion of genuine art, convincing the reader that "The stronger the infection, the better art as art, not to mention its content, that is, regardless of the dignity of the feelings that it conveys" (Tolstoy, 1985: 240).

But other forms of culture (for example, religion, myth) are also capable, in the language of Tolstoy, "infect" people, the whole culture is filled with human feelings. If we talk about aesthetic feelings, then what about the theories of pure beauty, which the writer categorically does not recognize?

In fact, Tolstoy replaces aesthetics with utilitarianism and utopianism: "Art, together with speech, is one of the tools of 


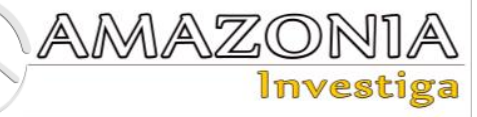

communication, and therefore progress, that is, the movement forward of mankind to perfection ... they replace erroneous and unnecessary knowledge, just as the evolution of feelings takes place through art, displacing lower feelings, less good and less necessary for the good of people with kinder, more necessary for this good" (Tolstoy, 1985: 242). In this case, art is presented as a way to achieve some kind of abstract good. The writer not only takes a utilitarian and antiaesthetic approach to art, he goes further, arguing that the real good must be separated from the beautiful.

However, belittling beauty in the name of good cannot be justified, especially when it comes to a religious context. Olivier Clement in this regard emphasizes: “... when faith is freed from any kind of moralism, it is able to respect in any beauty, no matter how "convulsive" it may seem, an attempt to "deepen into being". (Clement, 2004: 37.)

Speaking about the third component of the trinity, truth, the writer generally denies her the right to independence: "As for the truth, it is even less possible to attribute to this member of the imaginary trinity not only unity with good or beauty, but even some kind of independent existence" (Tolstoy, 1985: 180).

Leo Tolstoy, realizing that the idea of synthesis comes from the thinkers of antiquity, accuses the Greeks of the backwardness of ignorance and naivety: "The Greeks themselves were so poorly morally developed that goodness and beauty seemed to coincide, and on this backward worldview of the Greeks the science of aesthetics, invented people of the XVIII century and specially dressed in theory by Baumgarten" (Tolstoy, 1985: 178).

Moralizating is based on the moralist's belief that the moral collisions of the world have very real causes that can be eliminated with the help of common sense. This is the source of Tolstoy's utopianism and utilitarianism when it comes to understanding the essence and role of art, which the writer interprets exclusively as a way of moral improvement of people by artistic means.

Richard Niebuhr in his book "Christ and Culture", in the section "The Denial of Culture in Leo Tolstoy" compares the Russian writer with Tertullian, and his activities - with a crusade against culture. The theologian writes: "Tolstoy understands very little the meaning of the grace of God manifested in Jesus Christ, and the historical nature of Christian revelation, the psychological, moral and spiritual nature of both sin and salvation. Therefore, he turns out to be an even greater legalist than the lawyer Tertullian" (Niebuhr, 1996: 59).

It should be noted here that Tolstoy interprets the law as a kind of transpersonal and supracultural category, he does not think of it as a regulator of social life and does not evaluate it as a possible solution to specific human sorrows. Frolovsky writes: "Under the category of law, Tolstoy's goodness itself also disappears" (Frolovsky, 1983: 408). Niebuhr echoes him with theological fervor: "The law given by Christ is of much greater importance to him than the personality of the legislator himself" (Niebuhr, 1996: 59).

In addition, the ethics of law does not always work in the ontological abyss of a person's moral quest; it does not have enough potential to solve the ethical problems of the individual, which are associated with permanent tragic paradoxes of good and evil. The scientist Nekrasova asserts metaphorically and succinctly that "The ethics of the law ignores the fact that in our ultimate being the sun rises equally over the good and over the evil" (Nekrasova, 1997: 123-124).

The researcher Fedotov emphasizes that Tolstoy, interpreting the Gospel, paid attention only to those moments that directly concerned morality, leaving unnoticed whole layers filled with drama, tragedy, and complex spirituality. As a result, Tolstoy's rationalistic interpretation of the Gospel "simplified" it, made the content primitive. Fedotov concludes, full of sarcasm: "since Tolstoy began to interpret the Gospel, referring to it became a sign of bad taste ... it is possible to leave to the sectarians to dwell on the Sermon on the Mount" (Fedotov, 1998: 321).

In this regard, a comparative analysis of the religious ideas of Leo Tolstoy with the philosopher Nikolai Fedorov is indicative. S.G. Semenova shows Tolstoy's religious limitations, analyzing his sermons, criticizes his moral rationalism, the immunity of the mystical in Christianity. Tolstoy's creative power lies in his works of art, and not in theoretical and critical reasoning. "Tolstoy creates only an ethical utopia of a truly Christian world community, where brotherhood, love, justice reign through the universal fulfillment of the commandments of the Sermon on the Mount, where they work on the soul, perfecting it, enlightening it, without trying to penetrate the secrets of the world, let alone transform his laws" (Semenova, 2004: 247). However, Semenova also notes the 
strengths of Tolstoy, his similarity with Fedorov's ideas (Semenova, 2004: 147).

Scientist M.N. Boyko believes that only two questions are fundamental for Tolstov - about the meaning of life and about the essence of art. In a certain period of creativity, the meaning of life comes to the fore, and this, according to the researcher, contributes to the ambiguous interpretation of art by Tolstoy. "Tolstoy casts doubt on the assertion, habitually repeated by many critics and aesthetics, about the beneficial influence of art on the human soul. The real impact of real works, called artistic, in today's world seems to him to be largely negative, sometimes dangerous" (Boyko, 1997: 136).

Scientist A.B. Tarasov explores the attitude of Leo Tolstoy to the categories of truth and truth. He does not consider Tolstoy a Christian writer at all, accusing the latter of depriving Christ of the divine halo. Tarasov asserts that in his work Tolstoy carries out "the reduction of Christ to man, and Christian life and faith to moral and practical teaching" (Tarasov, 2001: 163). The critic connects with this the departure of Tolstoy to moralizing.

Researcher-ethicist O.S. Soina, in turn, also emphasizes the uniqueness of Tolstoy's talent, calling the writer's gift "spiritual titanism", emphasizing, however, that the source of this gift is the writer's exclusive awareness of universal injustice, primarily on himself. As a result, a powerful protest against history, culture, church, the foundations of the universe itself. Soina believes that "... we are meeting here with the autonomy of deadly morality and life-giving spirituality, which is very characteristic of Russian moralistic ethics - an antinomy, which, in all likelihood, is the ideological tragedy of L. Tolstoy himself, the psychological nerve of his fate and the secret of his personality" (Soina, 1995: 126).

It seems that the above researchers are right, since the work of Leo Tolstoy, his rational moralism had a significant impact on the massive secularization of pre-revolutionary domestic and Soviet culture.

\section{Conclusion}

It turns out to be logical that, despite the rational moralism in his critical works and worldview, in his artistic work Tolstoy recreates the inner world of his heroes extremely aesthetically, as indicated, in particular, by P.V. Annenkov. "Art here is in a friendly attitude to the thought that is constantly present in the story ..." (Annenkov, 1982: 141).

In other words, in literary texts Tolstoy is revealed as a true artist. This happens because the literary text obeys other laws and at some point gets out of the rational control of the author, begins to exist as if by itself, which inevitably leads to the synthesis of Truth, Goodness and Beauty. This is a kind of apophaticism of artistic creativity, the problems of which are increasingly being addressed by modern researchers today (Dudareva 2019, 2021). "Tolstoy himself denies synthesis in the name of greater synthesis, he denies it not because it is not needed, or even not because it is not achievable, but because he longs for its absolute achievement" (Simonova, 2008: 146).

The categories of duty and morality are not sufficient grounds for the existence of art, which has a synthetic potential that translates spiritual values into real life. This is what Vl. Soloviev: "Perfect art in its final task must embody the absolute ideal not in one imagination, but ... must spiritualize, transubstantiate our real life" (Soloviev, 1988: 404). Reality needs its transformation with the help of beauty, so art inevitably includes all the components of the triad.

\section{References}

Annenkov, P.V. (1982) On thought in works of fine literature. Russian aesthetics and criticism of the 40-50s XIX century. M: Publishing house Art.

Astafiev, P.E. (1996) Nationality and universal human tasks (to Russian folk psychology). Problems of Philosophy. M. № 12, pp. 84-102.

Bibikhin, V.V. (1998) New Renaissance. - M.: Nauka, Progress-Tradition. 496 p.

Boyko, M.N. (1997) Self-Consciousness of Art - Self-Consciousness of Man: Essays on Russian Aesthetic Thought of the Second Half of the 19th Century. - M.: Nauka, 187 p.

Clement, O. (2004) Reflections of Light: An Orthodox Theology of Beauty. M.: BiblicalTheological Institute of St. Apostle Andrew, $100 \mathrm{p}$.

Dudareva, M. (2019). Apophatic elements in the poetry of S. A. Yesenin: Thanats' characters. Amazonia Investiga, 8 (22), pp. 51-57 https://amazoniainvestiga.info/index.php/amazo nia/article/view/27

Dudareva, M., Omuraliev, N. A, Shvetsova, T. V., \& Aripova, D. A. (2021). Apophatics of artistic culture: raising the issue. Disease, death and sleep ethoses in Alexander 


\section{AMAZONDA \\ 1nvestiga}

Grin's story "Struggle with Death". Amazonia Investiga, 10 (39), pp. 232-237. https://amazoniainvestiga.info/index.php/amazo nia/article/view/1590

Fedotov, G.P. (1998). In Defense of Ethics. Fedotov G.P. Sobr. Op. in 12 volumes. M.: Martis. - T.2.

Fetisov, V.P. (1995). Longing for Russian aristocracy Voronezh, Publishing house Kvadrat. $112 \mathrm{p}$.

Frank, S.L. (1990). Ethics of nihilism Frank S.L. Op. - M.: True.

Frolovsky, G. (1983). The paths of Russian theology. Paris. YMCA-Press.

Nekrasova, E.N. (1997) The Metaphysics of Human Being in Russian Religious Philosophy of the Twentieth Century. M: Martis Publishing House, $160 \mathrm{p}$

Niebuhr, H. R. (1996) Christ and Culture. M: Lawyer Publishing House.

Paramonov, B.M. (1999). End of Style. M.: Agraf, $575 \mathrm{p}$.
Semenova, S.G. (2004) Metaphysics of Russian Literature. M.: PoRog. - T 1. - 510 p.

Shpet, G.G. (2007). Art as a Kind of Knowledge: Selected Works on the Philosophy of Culture. M.: ROSSPEN.

Simonova, S.A. (2008) Architectonics of Culture: Problems of Ethical and Aesthetic Synthesis. Voronezh: Voronezh State University Publishing House, 218 p.

Soina, O.S. (1995) The Phenomenon of Russian Moralizing: Ethical Essays. Novosibirsk: Science, $200 \mathrm{p}$.

Soloviev, V.S. (1988) The general meaning of art. M., Mysl Publishing House, in 2 volumes, Vol. 2, 892 p.

Tarasov, A.B. (2001). What is Truth? The Righteous of Leo Tolstoy. M.: Languages of Slavic culture, $172 \mathrm{p}$.

Tolstoy, L.N. (1985) What is art? M: Sovremennik Publishing House. 592 s. 